\title{
Calvyn en die Calvinisme
}

\author{
BJ Engelbrecht
}

Abstract

Calvin and Calvinism

The theology of Calvin had and still has a worldwide influence. During the course of history, theologians suggested various themes as the central theme of Calvin's theology around which it is possible to structure all the aspects of his theological thought to a coherent system. It is a question if this is really possible without a lesser or greater measure of distortion of Calvin's own theological thought. In this article two 'central themes' are treated, that is the theme of the soli Deo gloria and the theme of the sola et tota Scriptura. In each case Calvin's own thinking on the subject concerned, is described and then the various interpretations in history of the theme concerned are treated. In this way trends in calvinistic thinking and groups such as Kuypers Neo-Calvinism, the Social Gospel, the rationalistic Orthodoxism, the methodistic Pietism, the Enlightenment, theological Liberalism and modern hermeneutics are broached. Finally, ensuing from this, the most important issues to be adressed presently in Calvinistic thought, are identified.

\section{INLEIDING}

Vir meer as dertig jaar het ek die 1559 uitgawe van Calvyn se Institusie vir my BD-studente vir hulle dogmatiekstudie voorgeskryf. Hulle moes dan die Institusie in drie jaar sistematies deurwerk. Natuurlik was dit nie die enigste voorgeskrewe boek nie, maar tog een van die belangrikstes. Met my DD-studente het ons gereeld capita selecta uit Calvyn, veral uit sy Institusie, in diepte behandel. Dit het onder andere meegebring dat ek van tyd tot tyd oor aspekte van Calvyn se denke gepubliseer het. Hierdie artikels en verdere artikels oor veral die sogenoemde Nuwe Teologie, word in die literatuuropgawe aangegee, en ek het in hierdie voordrag (Predikantevergadering, 1981) ruim van hierdie artikels gebruik gemaak deur onder andere daarna te verwys vir uitvoeriger behandeling van sekere probleemkompekse rondom die teologie van Calvyn. Verder het ek ruim gebruik gemaak van die volgende vier boeke, naamlik: diě van Bouyer (1963), McNeill (1967), Kelsey (1975) èn 
die skitterende artikel van Klooster (1979), waarvan die besonderhede in die literatuuropgawe verskyn.

\section{2. 'N METODIESE PROBLEEM}

As 'n mens na die boek van McNeill (1967) kyk en ook prakties met Calvinistiese teoloë en kerke anders as jou eie praat, dan sien jy dat elkeen van hierdie verskillende variante van die Calvinisme oortuig is dat hulle histories én inhoudelik in die huidige tydsgewrig die eintlike legitieme voortsetting van die teologie van Calvyn is. As 'n mens nou dit wat Calvyn gedink en geleer het, wil stel teenoor die verskillende vorms van Calvinisme, is die probleem: Watter waarborg het ' $n$ mens dat jou eie interpretasie en weergawe van Calvyn nader aan die oorspronklike Calvyngedagtes staan as die interpretasies en weergawes van die verskillende ander variante van die Calvinisme. ' $n$ Poging tot oplossing van hierdie metodiese knelpunt, is dat ' $n$ mens sal probeer om Calvyn self aan die woord te stel en veral die tipiese hoofgedagtes van Calvyn waarin hy hom stel teenoor Rome en die Wederdopers (maar óók teenoor Luther en Zwingli) na vore sal bring.

\section{SOLI DEO GLORIA AS HOOFPUNT VAN CALVYN SE LEER}

\subsection{Calvyn}

Bouyer (1963: 28) sê dat die hoofontdekking van Luther die feit is dat die mens alleen deur die genade, deur die geloof gered word (sola fide, sola gratia). 'What, in principle, it aims at rejecting is, alone, the idea we have to add our personal quota that is something external to these two things, grace which gives, and faith which receives.' Verder stel Bouyer die volgende oor 'the insight of Luther' naamlik, dat dit 'is preserved in the type of Protestantism most faithful to its origins and most truly Christian,' naamlik: 'that all is grace, and that, consequently, all our salvation comes to us by faith. If this all is compromised, the very heart of Protestant spirituality is wounded mortally' (al die beklemtoning deur Bouyer self). Volgens Bouyer (1963: 29) was dit Melanchton 'who drew up a systematic statement of the essential tenets of the movement' (i e Protestantism).

It was he who adopted the expression sola gratia, sola fide as the 
basic principle of the Reformation. However to this basic, or material principle Melanchton added as a necessary presupposition, what he called the formal principle - namely, the supreme authority of Scripture. For if Luther found out at Erfurt, salvation is a grace, a pure gift to be received by faith, neither our reason nor any human endeavour can attain in the realm of thought what our will is powerless to reach in reality. Divine revelation alone can make known to us the divine action; both are equally gratuitous gifts ... Herein lies the positive value contained, from the beginning, in the second Protestant principle: the supreme authority of the Bible. It signifies, primarily, a return to the essential. We can be saved because God has acted. We can believe in his action because He has spoken to us (Bouyer 1963: 29-30).

Bouyer werk dan hierdie materiële beginsel van alle egte Protestantisme uit in 'n hoofstuk met die titel: 'The Free Gift of Salvation' en in 'n ander hoofstuk 'Justification by Faith and Personal Religion', terwyl die formele beginsel uitvoerig behandel word in ' $n$ hoofstuk getitel: 'The Sovereign Authority of Scripture'.

Calvyn het bogenoemde materiële en formele beginsels uiteraard gemeenskaplik met alle ander Reformatore besit. Wanneer Bouyer die tipiese van Calvyn wil aandui, dan stel hy (Bouyer 1963: 90-122) dat Calvyn die Lutherse beginsel van die sola gratia tot die 'beginsel' van soli Deo gloria gereduseer het. Eintlik fungeer die soli Deo gloria by Calvyn gladnie 'as an isolated theological thesis' nie, 'but what now concerns us, is a view embracing the whole of theology and of religion too, a vision, sweeping and definitive, of the world and all that lies beyond'. Hierdie siening is 'a doctrine and way of life centred on the glory of God alone' (Bouyer 1963: 90). Met verwysing na die Institusie I, 23 stel Bouyer:

The only knowledge that counts, is what makes us recognise His sovereign power, and so to expect all from Him and to consecrate ourselves, entirely and exclusively, to his glory (Bouyer 1963: 92). Nothing could show more convincingly that, for Calvin himself, the soli Deo gloria is not only a sublime theory furnishing a base for preaching the fundamentals of Protestantism, but a magnificent religious, even mistical, vision, which ought to inspire the whole life of the Christian ... the same motive is at work in the heart of the Calvinist doctrine ... of predestination (Bouyer 1963: 95).

...The only thing capable of giving absolute security is the pure 
will of God ... whose sovereign freedom is known by his own revelation (Bouyer 1962: 96).

If we now pass the sphere of worship and the Church to the community and the social and political life Calvin desired to build up round this centre, the subjection of this community and the consecration of its public life to the soli Deo gloria will appear no less vividly (Bouyer 1962: 103).

As voorbeeld hiervan noem Bouyer die teokrasie wat Calvyn in Genéve verwesenlik het.

This amounts to saying that civil life is to be, in principle entirely dominated by the Word of God, ruled by the sovereign will it proclaims, and so tending wholly to the sole glory of the absolute sovereign there revealed (Bouyer 1962: 104).

For Calvin justification, if genuine, is prolonged into a sanctification which is effective externally (Bouyer 1962: 105).

Not only the Church within the City, but the city in its entirety has to be built up, in his view, by and for the progressive sanctification of man justified, so that, in the words of the apostle, 'in all things God may be glorified' (Bouyer 1962: 107).

Ekself het hierdie motief van Calvyn se teologie breër uitgewerk en die agtergrond en breër verbande daarvan aangetoon in die artikels oor 'Die prinsipiële patroon van die Calvinisme vandag' (Engelbrecht 1978b), die artikel oor 'Calvyn en die corpus christianum' (Engelbrecht 1979b) en oor 'Die Godsdiens van die Afrikaner' (Engelbrecht 1979d).

Daar het ons onder andere gestel dat Calvyn die ganse lewe nie losgemaak het van die oorheersing deur die kerk (ekklesiokrasie) en van die bygeloof (superstitiokrasie) om dit in hulle eie terme te verstaan nie (outonomie), maar om hulle sub specie Aeternitatis te verstaan en tot eer van God uit te leef. Juis omdat Calvyn met die helder lig van Gods Woord die geskape werklikheid geontmitologiseer, geontmasker en gerelativeer het, daarom is dit gewone werklikheid en is dit nie gelaai met magiese kragte nie en daarom mag die mens dit bewerk en tot eer van God omvorm. lets van die herskepping van dié werklikheid wat geskep is, maar daarna in sonde geval het, moet ook hier-en-nou deurskemer.

Waar Luther meer gekonsentreer het op die persoonlike vraag van: 'Hoe word ek salig?' het Calvyn besef dat die Woord van God, behalwe Evangelie ook Wet is, ook lewensreël en lewensnorm wat aan die 
totaliteit van die lewe vorm en gestalte moet gee tot eer van God. Die ontdekking dat die Skrif die enigste bron en norm van ons geloof is, hou ook in dat die Skrif die enigste bron en norm van ons lewe is. Hierdie Skrif leer dat ons uit genade alleen, deur die geloof alleen voor God regverdig is, maar dit leer ook dat die regverdiging nooit sonder die heiliging kan bestaan nie, nooit sonder dié heiliging wat uit dankbaarheid konkrete gestalte aan al die fasette van ons persoonlike lewe en van die openbare lewe gee nie. Daarom kan ons praat van 'n 'Totalgestaltung des Lebens' by Calvyn. In plaas van ekklesiokrasie (soos by Rome in die Middeleeue) of tegnokrasie en outonomie ('n gevaar by ons vandag), stel Calvyn die beginsel en werklikheid van die teokrasie deur die Woord en Gees in die geloof en heiliging.

\subsection{Sekere strominge van Calvinisme}

'n Hele aantal strominge van die Calvinisme het by dié motief (en veral by sy nadere uitwerking deur Calvyn) aangesluit en beskou hulleself as legitieme voortsettings van die hoofgedagtes van die Kerkhervorming en spesifiek van Calvyn. Ons stip slegs die volgende aan:

\subsubsection{Die sogenoemde 'Neo-Calvinisme' wat by dr Abraham Kuyper aansluit}

Kuyper gaan saam met Calvyn uit van die volstrekte-soewereine God wat Hom in sy Woord openbaar; wat die gelowige betref, is dit sy roeping om Hom te ken, te dien en te verheerlik op alle terreine van die lewe. Alle skepsele is volstrek afhanklik van God se raad; buitendien is die mens sondig en daarom onmagtig om te glo en uit die geloof te lewe. Dit is slegs die verkiesende genade van God wat langs die weg van die verbond 'n gemeente grond op die heilswerk van Jesus Christus en deur die Heilige Gees toerus, roep en bekwaam maak om God met alles wat hulle besit, in alle lewensuitinge in die proses van hulle heiligmaking gehoorsaam te wees, te dien en te verheerlik (vgl Nauta 1955, Encyclopedie van het Christendom, Prot D1 bl 250).

Die vraag is nou: Hoe kom hierdie wêreldveranderende lewens- en wêreldbeskouing in die mens tot stand en hoe moet dit prakties geïmplimenteer word? Kuyper antwoord (kyk onder andere Van der Leeuw 1948: 36-42): Die wedergeboorte as soewereine daad van die verkiesende God, is nie maar iets wat die wedergeborene oppervlakkig raak nie; veeleer is dit ' $n$ gebeurtenis wat die mens se hele eksistensie (en van daaruit al sy lewensuitinge) totaal omvorm. Die wedergebore 
mens ervaar, interpreteer, bedink en sien alles in die lewe anders as die onwedergeborene. Prakties word dit soos volg geïmplimenteer: Die gereformeerde gelowiges (wedergeborenes) bedryf anders wetenskap as die ongelowige. Daarom kom die Vrije Universiteit tot stand. Hy sien en interpreteer die gebeurtenisse en politieke sake van die dag anders as die onwedergeborene. Daarom kom daar 'n Christelike pers en later radio en televisie tot stand. Hy sien en interpreteer die politiek (in sy volle omvang) anders as die onwedergeborene en so kom die Antirevolusionaire Partij tot stand. Op dieselfde wyse sal die egte gereformeerde gelowiges vanuit die wedergeboorte hulle visie en invloed (of as individue ò as lede van 'n Christelike Vereniging) laat geld op elke enkele terrein van menslike aktiwiteit en samelewing.

Alreeds die feit dat die gereformeerde gelowiges as individue of deur middel van ' $n$ Christelike Vereniging hulle invloed en visie as gelowiges in die wêreld sal laat geld, bring Kuyper se opvatting oor die vrye kerk en vrye staat na vore. Daarmee wou hy die gevaar van ekklesiokrasie soos by Rome afwys, maar daardeur het hy ons insiens dié eg-Calvynse teokrasie waarby die kerk direk betrokke is, prysgegee. Ek glo dat hier ook die wortels lê van sy afwysing van die 'volkskerk'gedagte; nie die volkskerk in die sin dat die toebehorentheid aan die volk tegelyk toebehorentheid tot die kerk impliseer nie; ook nie in die sin dat die 'volkskerk'-gedagte die sendingvisie van die kerk (wat gerig is op alle volke, tale en nasies) onmoontlik maak nie, maar 'volkskerk' soos onder andere uiteengesit in Botha (1973); Engelbrecht (1979b) en Van der Westhuizen (1981).

Dit is seker nie die bedoeling om hier volledige kritiek op die Neo-Calvinisme van Kuyper en die verdere uitwerking van sy gedagtes in Nederland en in Suid-Afrika (onder andere aan die PU vir CHO en UOVS) te lewer nie. Dit is bekend hoe dat die gedagte van die Christelike Wetenskap uitgewerk is in Dooyeweerd-Vollenhoven se Wysbegeerte van die Wetsidee en Stoker se Wysgebeerte van die Skeppingsidee. Hiervolgens spreek die Wedergeboorte nie net mee in die refleksie oor en evaluering van die resultate van die wetenskappe nie, maar ook in die fases van materiaalversameling én in die wetenskaplike interpretasie én ordening in 'n samehangende patroon. In sekere Geesteswetenskappe soos die Teologie en Geskiedenis mag dit nog opgaan, maar dit word 'n vraag of dit ooit op die Natuurwetenskappe van toepaasing kan wees? Vir 'n kritiese beoordeling van hierdie aspek van Kuyper, verwys ek graag na Antonites (1982).

Verder noem ons net die Kuyperiaanse kerkbegrip en opvatting van 
die 'outonomie van die plaaslike gemeente' in sake kerkregering. Ons beskou dit as 'n definitiewe afwyking van die oorspronklike gedagtes van Calvyn, maar ons sit dit hier nie verder uiteen nie en evalueer dit ook nie krities nie. Ons kerk se standpuntinname in hierdie verband is onder andere vervat in die memoranda van ons kerk vir die gespreksvoering in die Tussenkerklike Kommissie. Dit lê ter insae by die kantoor van die Skriba van ons kerk.

Ten slotte wil ek net stel dat ek glo dat selfs Kuyper sou toegee dat sy Calvinisme 'n eie wending en visie van Calvyn se gedagtes is, ' $n$ eie opvatting binne'n bepaalde denksisteem wat Calvyn se gedagtes wou aanpas by die eise van die moderne lewe.

Die tweede rigting van Calvinisme wat ek in hierdie verband wil noem, is die politieke teologie van die Social Gospel wat vandag sy uiting onder andere in die sogenoemde Nuwe Teologie vind.

Volgens McNeill se aangehaalde werk lê die wortels hiervan baie ver terug in die geskiedenis. Die historiese oorsig van die Calvinisme se betrokkendheid by maatskaplike en politieke vrae (McNeill noem dit 'Calvinism and public affairs' onder die hoofstuk 'Calvinism and modern issues') kan by McNeill (1967: 411-425) gelees word. Ons stel slegs die volgende: Die aansluitingspunt van hierdie rigting by Calvyn, is juis die teokratiese gedagte van Calvyn, die omvorming, kerstening en heiliging van alle lewensfasette tot eer van God.

Die Industriële Revolusie het die gaping tussen ryk en arm vergroot en die armes totaal afhanklik van die besittersklas gemaak. In aansluiting by Calvyn se visie van die wêreldvernuwende krag van die Evangelie, het mense soos Thomas Chalmers hierdie probleem van 'dependence poverty' aangepak. Hy het 'parochial assosiations' gestig en groot vertroue gehad in die sosiaal-hernuwende krag van godsdienstige en sedelike opvoeding vanuit die Bybel. Op dieselfde wyse het die Anglikaanse Christelike Sosialisme probeer om 'n Christelike antwoord op Marx se Manifesto van 1848 te gee en het die 'Social Gospel' in Amerika in aansluiting by Ritchl se Teologie van die Waardeoordele en die Koninkrykgsgedagte ontstaan. Die name van Gladden en veral van Walter Rauschenbush is bekend. McNeill sê: 'In its forthright attack upon social evils and demand for reform, the Social Gospel partook of the spirit of Calvinism' (Mc Neill 1967: 423). So is dan die 'Federal (later 'National') Council of Churches' gevorm (onder andere deur die 'Presbyterian and Reformed Chuches' in America). Hulle het die verkryging van rykdom ondergeskik gestel aan sosiale welsyn en het onder andere sterk pleidooie gelewer vir vryheid van 
spraak, van die pers, van assosiasie en byeenkoms. Dit is te vinde in hulle 'Social Creed of Churches' van 1912.

Hoe hierdie denke gelei het tot (en aansluiting gevind het by) die sosiale denke en praktiese program van die Wêreldraad van Kerke, het ek onder andere aangetoon in my artikel oor die Cottesloe-beraad (Engelbrecht 1975: 13-20) en hoe dit onder andere ook gelei het tot die 'Teologie van die Hoop' en die 'Teologie van die Revolusie' het ek behandel in 'Hedendaagse krisispunte in die Teologie' (Engelbrecht 1978a: 222-238) èn in 'Die teologie van die hoop en die teologie van die revolusie' (Engelbrecht 1974: 31-51). Daarom herhaal ons dit nie weer hier uitvoerig nie, maar stel ons slegs dat ook hierdie rigtings meen dat hulle legitieme voortsettings is van Calvyn se teokratiese gedagte van die Totalgestaltung des Lebens in die proses van die sanctificatio. Hulle voer die teokrasie deur via die Ritschelse Koninkryksteologie tot die teologie van die kerstening en voortdurende verandering van 'die strukture' deur middel van die kerk as permanente eksodusgemeente. Maar wie hierdie teologie noukeurig lees, merk dadelik op dat hierdie wëreldvernuwing nie meer gerig is op die soli Deo gloria nie, maar op die proses waarin die 'gelowige' hier-en-nou sy historiese verantwoordelikheid tot humanisering moet aanvaar.

'n Derde rigting in die moderne teologie wat by die hoofpunt van die soli Deo gloria aansluit, is die volgende: Ons het alreeds daarop gewys dat Calvyn (voordat hy gestel het dat die gelowige op alle terreine van die lewe, die wêreld moet omvorm tot eer van die soewereine God) die werklikheid geontmitologiseer het. Dit beteken dat hy teenoor die heidendom én teenoor die middeleeuse bygeloof aangetoon het dat die werklikheid gewone geskape werklikheid is en nie met magiese kragte gelaai is sodat dit onbeheerbaar is en selfs afgodies vereer moet word nie. Deur hierdie ontmitologisering, relativering en selfs sekularisasie van die werklikheid, word dit vir die gelowige moontlik om dit (die werklikheid) deur die genade van God tot sy eer te omvorm.

Maar, sê sommige moderne teoloë (kyk Engelbrecht 1978a vir verdere besonderhede): Calvyn het nie ver genoeg gegaan in sy 'sekularisasie', sy ontmitologisering nie. Die moderne mens, so stel hulle, wil niks meer aanvaar wat nie deur almal meetbaar en kontroleerbaar ervaar kan word, daarna in 'n logies-samehangende patroon georden kan word en uiteindelik geverifieer kan word nie. Daarom aanvaar die moderne mens nie meer die mitologiese dinge soos ' $n$ onkontroleerbare hemel en God daarbo en ' $n$ hiernamaals nie. Hulle het genoeg aan die mens Jesus van Nasaret as ' $n$ inspirerende morele, sosiale en politieke leier en 
voorbeeld vir ons vandag. Daarom meen hierdie teoloë dat hulle die motiewe van die Reformatore (en in hierdie opsig van Calvyn) konsekwent deurvoer. So praat JAT Robinson in sy boek wat ná sy opspraakwekkende Honest to God verskyn het, van 'A New Reformation?' (Robinson 1963; 1965).

Ook hier gee ons geen kritiek nie, maar stel net die feit dat selfs hierdie uiters linkse teoloë meen dat hulle legitiem by Calvyn aansluit en sy gedagtes voortsit.

\section{SOLA SCRIPTURA EN TOTA SCRIPTURA AS 'N (TWEEDE) MOONTLIKE HOOFPUNT VAN CALVYN SE LEER}

\subsection{Calvyn}

In sy genoemde artikel 'The Uniqueness of Reformed Theology. A Preliminary Attempt at Description', stel Fred H Klooster (1979) dat daar in die loop van die geskiedenis deur Calvynnavorsers verskillende 'hoofpunte' voorgestel is as dié sentrale gedagte in Calvyn se teologiese denkarbeid. So is daar die volgende genoem:

- Die leerstuk van die predestinasie.

- Die leerstuk van die verbonde.

- Die leerstuk van die volstrekte sowereiniteit van God.

- Die leerstuk van die soewereine genade van God.

- Calvyn se Koninkryksperspektief.

- Calvyn se kultuur-omvormingsperspektief.

- Die motief van die heiliging.

Die Calvyn-navorser Wilhelm Niesel stel die volgende basiese of sleutel-temas voor:

- Die soewereiniteit van God.

- Die Dei Gloria.

- Die predestinasieleer.

- Die Godsbegrip, veral die tema van die regverdige of van die lewende God.

- Die leerstuk van die genadige wil van God.

- Die brug tussen openbaring en rede.

- Die leerstuk van die skepping. 
Karl Barth, Eugene Oosterhaven en JH Leith meen dat die volgende die tipiese trek van Calvyn se denke is:

- Die ootuiging dat ons met die lewende God te doen het en dat ons ons lewe voor Hom moet heilig en aan Hom moet wy.

Ten slotte kan nog die volgende temas genoem word as moontlike kerngedagtes van Calvyn:

- Die leerstuk van die besondere uitverkiesing en verlossing.

- Die morele onvermoë van die mens in sy gevalle staat en daarom die volstrekte afhanklikheid van die mens van die soewereine wil van God.

- Die leerstuk van die onwederstandelike genade.

- Die leerstuk van die volharding van die heiliges en die sekerheid oor ons saligheid.

Klooster meen dat elkeen van hierdie voorgestelde sogenaamde tipiese basiese sleutelbegrippe in verband met Calvyn se teologiese denke belangrik is en 'n sekere element van waarheid verteenwoordig, maar dat hulle almal afsonderlik (én in hul gesamentlike verband) deur één kernbeginsel gedra word waaruit elkeen voortvloei, naamlik die sola Scriptura en tota Scriptura. Hy wys daarop dat nadat Wendel sekere moontlike sentrale temas van Calvyn se denke (soos die predestinasie, die goddelike soewereiniteit, die eskatologie, die eer van God, die persoon van Jesus Christus) opgenoem het, hy uiteindelik konkludeer dat alles in Calvyn se denke, ook die logiese paradokse daarin, uiteindelik te herlei is na sy 'nougesette getrouheid aan die Bybel'. Calvyn se reël is: 'Spreek wanneer en wat die Skrif sê, maar swyg wanneer die Skrif swyg'.

Leith (1973: 97) wys daarop dat die eerste tese wat die Reformatore in hulle disputasies met Rome voorop gestel het, dit is dat die Bybel in die teologie die beslissende gesag het. Ekself verwys altyd graag na die eerste van Zwingli se 'Sewe-en-sestig Artikels' van Januarie 1532: 'Elkeen wat sê dat die Skrif niks is sonder die goedkeuring van die kerk nie, dwaal en smaad God' (Zwingli 1532: 1). Van sy Institusie (die inleiding van die 1539 uitgawe) sê Calvyn (teenoor die dik spekulatiewe Summae by Rome) dat dit 'niks anders is as ' $n$ inleiding om sy studente na die Heilige Boek te lei om dit (die Bybel) beter te verstaan nie'. Dieselfde kry ons ook in die inleiding van sy 1559 uitgawe. 'Dit was my doel om die kandidate in die heilige teologie, voor te berei en daarin 
onderrig te gee om die goddelike Woord te leer lees'. Die Institusie is 'die sleutel om die weg vir alle kinders van God om die Heilige Skrif te verstaan, oop te sluit ... die Heilige Skrif bevat ' $n$ volmaakte leer waarby niks gevoeg kan word nie'. Die Institusie leer mense 'waarvoor hulle in die Skrif moet soek en hoe hulle dit met mekaar in verband moet bring'. Omdat sy Institusie 'n soort inleidende en sistematiese kommentaar op die hoofpunte van die Skrif en 'n gids vir Skrifstudie is, daarom (sê Calvyn) kan hy selfs korter in sy kommentare oor die Skrif skryf. Wanneer hy oor die Drie-eenheid (Inst I, 13, 3) skryf, dan sê hy dat ons hier nie moet spekuleer nie, maar net 'die Skrif as die vaste reël vir beide ons dink en praat moet neem'. Dieselfde sê hy (natuurlik teenoor die ontsaglike spekulasie van Rome in hierdie verband) wanneer hy oor die engele praat (Inst I, 14. Kyk ook Klooster 1979: 41-44).

Die Skrifbeginsel waaruit al die ander karakteristieke leerstukke van Calvyn gevloei het, was dat die Skrif deur die werking van die Heilige Gees vir alle teologiese denke noodsaaklik is (necessitas Sacrae Scripturae), maar tegelyk ook selfgeloofwaardig (autopistos), volmaak (perfectio SS) en uit sigself duidelik (perspicuitas SS) (Kyk byvoorbeeld Art VII, NGB). Vir hom het nie alleen gegeld: Sola Scriptura nie, maar ook tota Scriptura. Hy het ten volle erns gemaak met Deuteronomium 4 vers 12 , 12 vers 32 en Openbaringe 22 vers 18 en 19 wat hy op die hele kanonieke Skrif toegepas het, naamlik dat daarby niks bygevoeg of van weggeneem mag word nie. Natuurlik het dit nie beteken dat alle gedeeltes van die Skrif vir Calvyn eweveel gewig gedra het en alles ewe relevant ten opsigte van 'n bepaalde etiese of leerstellige probleem was nie. Hy het die belangrikheid van elke Skrifgedeelte deur die Skrif self laat bepaal (dit wil sê deur hulle sistematiese, historiese en literêre konteks). In hierdie verband merk Klooster (1979: 50) op: 'Reformed (i e true Calvinistic) theologians sought to integrate the whole of Scripture into a coherent system of doctrine that did justice to the harmony of Scripture, the unity of the history of redemption, and the historical progress of revelation ... emphasizing the historical covenants by which God structured his relations with the chosen people'. Dit laat myns insiens ook teoloë van die statuur van Brevard S Childs die kommentare van Luther, maar veral van Calvyn (spesiaal dié oor die $\mathrm{Ou}$ Testament) baie hoog aanslaan en aanbeveel.

Maar in hierdie laaste sitaat uit Klooster lê alreeds een van die hoofprobleme opgesluit wat in die moderne hermeneutiek na vore getree het, onder andere by James Barr (1962 en 1977), WS Vorster (onder andere 1977 en 1981) en waaroor ook JA Loader (1978) en AG van 
Aarde (1978) in die Hervormde Teologiese Studies geskryf het (kyk ook Engelbrecht 1978). Hierdie rigting in die hermeneutiek raak juis die vraag na die 'harmony of Scripture' en die 'unity of the history of redemption'. Die teologiese punt waaroor dit gaan, is die probleem van sistematisering van Bybelse stof wat vir beide die vakke Bybelse Teologie én Dogmatiek belangrik is. Natuurlik het hierdie probleem alreeds in die agtiende eeu ontstaan met Johann Salomo Semler, die vader van moderne Bybelkritiek. Klooster verwys in hierdie verband onder andere daarop dat Barth in 1923 gestel het dat in plaas van 'n lewende, bewegende, lewenskragtige Calvinistiese teologie, die Gereformeerde teologie deur vier mure (strominge) ingekerker word, naamlik die Ortodoksie, die Piëtisme, die Verligting en die Liberalisme. Merkwaardig is dat elkeen van hierdie rigtings (dit wil sê in hulle kerlike gestaltes altans) daarop aanspraak gemaak het dat hulle die legitieme voortsettings van Calvyn se gedagtes is.

Die motief van die Ortodoksie (kyk bv Brunner 1929: 18,69) is om die gesag van die Skrif en die skriftuurlike dogmas ongeskonde te bewaar. Hulle is daarvan oortuig dat as jy hierdie gesag laat vaar, dat die hele Christelike geloof en godsdiens dan in duie sal stort en dat dit dan aan die menslike rede, wil en wense uitgelewer sal wees. Die probleem is egter dat hulle in hulle Skrifbeskouing uiters fundamentalisties (in die ou sin van die woord) is en aan 'n taamlike letterlike inspirasie vashou waarin alles in die Bybel gelyke goddelike gesag dra. In hulle dogmabeskouing word egte geloof gesien as die onvoorwaardelike aanvaarding van sekere leerstellige waarhede in plaas van ' $n$ lewende verhouding met die lewende God self.

Die Piëtisme is juis ' $n$ protesbeweging teen hierdie dorre leerstellige prediking en die uiterlike vir-waar-hou van sekere starre leerstellings. Hulle wou 'n beleefde geloof hê wat die hart, mond en daad omspan. Maar algaande het hulle wettieser geword en nie aan 'n eiegeregtige hoogmoed ontkom nie; ook nie later aan 'n starre metode van toeeiening van die heil nie. Teenoor die starheid van leer (by die ortodoksie) het ons hier 'n starheid van belewingsmetode en 'n wettiese hoogmoed gekry. Dikwels is die Skrif slegs tot impuls en aanleiding vir die belewing gedegradeer.

Basies beteken die Verligting dat alles wat nie die toets van die regbank van die rede kan deurstaan nie, nie wetenskaplik (en daarom nie werklik) aanvaarbaar is nie. Toegepas op die gebied van die teologie, beteken dit dat daar ten opsigte van die Skrif 'n aansienlike reduksie plaasgevind het. Op dié wyse is al die wonders (soos die 
maagdelike geboorte) en wonderwerke van Jesus sogenaamd 'uitgesuiwer'. Later het dit selfs wyer uitgekring en is alles wat nie aan die streng reëls van wetenskaplike geskiedskrywing voldoen nie, as onaanvaarbaar bestempel. Dit het daartoe gelei dat veral die historisiteit (en daarom werklikheid) van die opstanding van Jesus Christus (en daarom ook die wederopstanding van die vlees en die ewige lewe en hiernamaals) sterk bevraagteken is. Binne hierdie raamwerk merk Klooster op:

Questions of theology and science, of hermeneutics and exegesis have surfaced as problems to a degree not recognized before. Such issues do make any reference to the Scriptural principle appear naive and simplistic today. Critical methodology seems to call the Scriptural principle into question.

Met verwysing na Kelsey se genoemde werk, toon hy aan dat die neiging by 'hedendaagse' teoloë bestaan om sekere aspekte of 'fokuspunte' van die Skrif uit te lig. So sien die Calvynnavorser BB Warfield dan die Skrif as normatiewe bron van leerstellinge; HW Bartsch as normatiewe bron van sekere begrippe of betekenisvelde ('concepts'). Vir GE Wright le die outoriteit van die Skrif opgesluit in 'the recital or narrative aspect of Scripture'. Vir LS Thornton lê die outoritatiewe, normatiewe van die Skrif 'in images', beeldgroepe; vir Tillich in simbole en vir Bultmann in mitiese vertellinge. Klooster stel dat hierdie opvattings 'reductionistic in contrast to Calvin's view' is. 'It is not the tota Scriptura that functions authoratively for these theologians' (Klooster 1979: 50). 'Calvin and other Reformed theologians did not restrict the authority of Scripture to some aspect of it. Sola Scriptura is accompanied by tota Scripture'. Calvyn en sy egte navolgers 'did not adopt a positivistic view of history, nor an existentialistic view of the gospel' (Klooster 1979: 51). Tog het die situasie vanaf Calvyn se tyd radikaal verander. Een van die redes was die opkoms van die moderne wetenskap 'which raised issues for Reformed theology which the Reformers could not have been expected to face in their day'. Twee norme vir wetenskaplikheid is feitlik as evangelie aanvaar, naanmlik 'neutrality and objectivity ... as hallmark of authentic science'. Egte Calvynteologie sal uit die sola et tota Scriptura vandag aan die volgende probleemvelde aandag moet gee: 'the nature of science, the character of theological science, the role of pre-understanding, proper methodology, the nature of verification' ensovoorts (Klooster 1979: 52).

Ons het hier nog geen aandag aan die vierde muur wat die Protes- 
tantse teologie volgens Barth inkerker, naamlik die liberalisme gegee nie en ook het ons nie nader ingegaan op die nuwere hermeneutieknie, dié hermeneutiek waarvan Ebeling en Fuchs meen dat die hele teologie daarin opgaan nie. Dit is ook nie vir ons doel hier brood-nodig nie. Wat ons wel kan stel, is dat albei 'n geweldige diversifikasie van standpunte (ook binne die kring van die Calvinisme) tot gevolg gehad het rondom die probleem wat ons hier behandel, naamlik die Skrifprobleem, die probleem van die sola Scriptura as tipiese grondgedagte van Calvyn. Ons verwys slegs in verband met die liberalisme na Engelbrecht (1979c: 142-150), en in verband met die nuwere hermeneutiek na Koekemoer (1972). In verband met die Skrifprobleem, kyk Bijlsma (1959: 488) èn die onlangse boek van HM Vroom, De Schrift alleen? (Vroom 1979).

\section{SLOTOPMERKINGS}

Ons program was om onder die twee gesigspunte naamlik die:

- soli Deo gloria, en

- sola et tota Scriptura

die tipiese trekke van Calvyn weer te gee.

By elke gesigspunt het ons óók die nadere uitwerking van daardie tipiese Calvyn-temas deur 'die Calvinisme', kortliks weergegee.

Wat hier by die 'nadere uitwerking van die tipiese Calvyn-temas deur die Calvinisme' geblyk het, is die geweldig groot diversiteit van standpunte en rigtings wat na vore gekom het (dikwels radikaalteenoorgestelde pole), terwyl elkeen van hulle, hulle tog op Calvyn self beroep. Wat voormheidstipe betref, vind 'n mens aan die een pool 'n sterk emosionele bevindelikheid en stigtelikheid (byvoorbeeld die Gereformeerde Bond in Nederland en die Walliese Calvinistiese Metodistekerk) en aan die ander pool, 'n streng rasionele, soms dorre, leerheiligheid. Wat Skrifbeskouing en bygevolg teologie betref, vind 'n mens aan een uiterste 'n krampagtige vashou aan die letterlike geïnspireerdheid en outoriteit van die Skrif tot in die fynste besonderhede (Fundamentalisme, Ortodoksisme); aan die ander uiterste vind jy 'n sterk krities-ingestelde Liberalisme en Modernisme. Wat die heil in en deur Jesus Christus betref, vind ' $n$ mens één rigting wat sterk op die innerlikheid van die mens en op die persoonlike saligheid die klem lê, terwyl 'n ander rigting sterk (en partymaal uitsluitlik) klem lê op die 
sosiale dinamiek en omvormingskrag van die heil in die wêreld; soms word hierdie rigting 'n sosiale en politieke evangelie wat gedurig die bestaande strukture afbreek, volkome diesseitig en sekulêr.

In sy historiese oorsig van die Calvinisme praat McNeill dan ook van 'The fragmentation of Calvinism' (1967: 353-373). Wie verder die gang van die Calvinisme wil nagaan 'in a changing world of thought', oor die 'reunion, expansion, and eucumenicty' van die Calvinisme, oor 'Calvinism and public affairs' en oor 'the spirit of Calvinism in the world today' (alles vanuit 'n historiese perspektief), verwys ons na McNeill (1967: 351-443). Hy skryf só kompak, dat 'n mens nie naastenby kan probeer om hom selfs opsommend weer te gee nie.

Hoe moet ons hierdie 'fragmentation of Calvinism' evalueer? Ons glo dat:

- eerstens die uitbreiding na ander lande en volkere met 'n eie mentaliteit, geestesklimaat en landsomstandighede, en

- tweedens die eise van 'n veranderende (en later) moderne wêreld,

baie daarmee te doen gehad het.

Tog glo ek dat die genoemde 'fragmentasie' dikwels daaraan te wyte was dat teoloë en rigtings slegs 'n gedeelte (al was dit 'n egte, legitieme gedeelte van (alvyn), geneem en dit uitgewerk het met verbygaan van die geheel en die verband. So, het ' $n$ mens dan byvoorbeeld (aa) die Calvinistiese bevindelikheid, (bb) én die klemlegging slegs op die dogma, slegs op die rasionele en leerstellige aspekte van die heil én (cc) die Neo-Calvinisme van Kuyper gekry, wat aldrie ook in 'n meerdere of mindere mate in die Calvinisme in ons land te vinde was (én is).

Maar wat van Calvyn vir vandag in die huidige tydsgewrig? Hierop wil ek antwoord dat nadat ek vir byna veertig jaar Calvyn se Institusie in my dogmatieklesings geintegreer het en ook oor sekere aspekte van sy teologie navorsing gedoen en gepubliseer het, is ek daarvan oortuig dat Calvyn vandag nog beslissende dinge vir ons te sê het. Daar moet in hierdie proses van die ter sprake bring van Calvyn vir vandag, egter aan twee voorwaardes voldoen word: Hy wat moet spreek, moet die hele Calvyn wees en nie net ' $n$ enkele aspek van sy denke nie. Tweedens: Hierdie spreke sal noukeurig rekening moet hou met die moderne mens wat die Verligting agter hom het, wat op die rasionele en objektiewe ingestel is, wat gevorm is deur die moderne wetenskapsbegrip en tegnologie en wat baie krities luister. Soos Klooster dit gestel het, en waarna ons alreeds verwys het: 
The nature of science, the character of theological science, the role of preunderstanding (vooronderstellinge - BJ E), proper methodology, the nature of verification - these are issues that must be given priority on today's agenda'.

Indien ons ons Calvynnavorsing in dié gees aanpak, sal dit sonder twyfel sin hê; nog meer: dit kan en sal dan 'n onskatbare, positiewe bydrae vir die teologie in die kerk en die verkondiging van die kerk lewer.

\section{Literatuurverwysings}

ANTONITES, JA 1982. Die wetenskapsbegrip by die Neo-Calvinistiese Wysbegeerte. Pretoria: Gutenberg.

BARR, J 1962. Biblical words for our time. London: SCM.

BARR, J 1977. Fundamentalism. London: SCM.

BIJLSMA, R 1959. Schriftuurlijk Schriftgezag. Nijkerk: Callenbach.

BOTHA, SJ 1973. Die volkskerk. Pretoria: HAUM.

BOYER, L 1963. The Spirit and forms of Protestantism. London: Fontana Library (Collins). BRUNNER, E 1929. The theology of crisis. London: Scribners.

CALVIN, J [1559] 1949. Institutes of the Christian Religion. Vertaling van H Beveridge. London: Clarke.

ENGELBRECHT, BJ 1974. Die teologie van die hoop en van die revolusie, in Die Bybel en die moderne mens. Pretoria: SA Akademie.

ENGELBRECHT, BJ 1975. Die Cottesloeberaad, in Van der Hoff Jaarblad. Pretoria: NHW Pers.

ENGELBRECHT, BJ 1978a. Hedendaagse krisispunte in die teologie, in Teologie in die Kerk. Pretoria: HAUM.

ENGELBRECHT, BJ 1978b. Die prinsipiële patroon van die Calvinisme, in Teologie in die Kerk. Pretoria: HAUM.

ENGELBRECHT, B] [1978c]. Nuwere ontwikkelings op die gebied van die Sistematiese Teologie. HTS 34/3 en 4.

ENGELBRECHT, BJ 1979a. Calvyn as grondlegger van die reformatoriese leer, in Temas rondom die Reformasie. Pretoria: HAUM.

ENGELBRECHT, BJ 1979b. Calvyn en die Corpus Christianum, in Temas rondom die Reformasie. Pretoria: HAUM.

ENGELBRECHT, BJ 1979c. Die bedreiging van ons Christelik-Nasionale erfenis ... deur die liberalisme, in Temas rondom die Reformasie. Pretoria: HAUM.

ENGELBRECHT, B] 1979d. Die Godsdiens van die Afrikaner, in Die kultuurontplooiing van die Afrikaner. Pretoria: HAUM.

KOEKEMOER, JH 1972. Die Christologie van die Nuwe Teologie: 'n Interpretasieprobleem. Pretoria: Universiteit van Pretoria.

KLOOSTER, F 1979. The uniqueness of Reformed Theology, in Calvin Theological Journal 14.

KELSEY, DH 1975. The uses of Scripture in recent theology. Philadelphia: Fortress.

LEITH JH 1973. Creeds of the Churches: A reader in Christian doctrine from the Bible to the present. Rev ed. Oxford: Blackwell.

LOADER, JA [1978]. Gedagtes oor gekontroleerde eksegese. HTS 34/1 en 2.

MCNEILL, JT 1967. The history and character of Calvinism. New York: OUP. 
NAUTA, D 1955. Abraham Kuyper (1837-1920), in Encyclopedie van het Christendom. Amsterdam: Elsevier.

ROBINSON, JAT 1963. Honest to God. London: SCM Press.

ROBINSON, JAT 1965. A new reformation? London: SCM Press.

VAN AARDE, AG [1978]. Moderne semantiek en formele homilitiek. HTS 34/1 en 2, 41-56.

VAN DER LEEUW, G 1948. Inleiding tot de Theologie. 2de Druk. Amsterdam: JH Paris.

VAN DER WESTHUIZEN, HG 1981. Volkskerk en sending. Pretoria: HAUM.

VORSTER, WS 1977. ' $n$ Ou Boek in 'n nuwe wêreld: Gedagtes rondom die interpretasie van die Nuwe Testament. Pretoria: Unisa.

VORSTER, WS 1981. Wat is 'n evangelie? Pretoria: NG Kerkboekhandel.

VROOM, HM 1979. De Schrift alleen? Kampen: Kok.

ZWINGLI, H [1532] 1913 Zeven en zestig Artikelen. Vert G Oorthuys. Nijkerk: Callenbach. 